\title{
HISTORY OF PATHOLOGY AT ST. THOMAS'S HOSPITAL, LONDON
}

\author{
by \\ W. D. FOSTER AND J. L. PINNIGER
}

ThE history of the departments of pathology of St. Thomas's Hospital dates from the appointment of John Simon as lecturer in that subject in 1847 . Since that time there has been a constantly growing collection of men and facilities devoted to the study and teaching of pathology in its various aspects.

Naturally, the study of pathology, as represented by morbid anatomy, had been pursued for many years before this, certainly as far back as the seventeenth century. We have interesting evidence of the study of morbid anatomy at the hospital in that period. Between the years 1674 and 1677 one of the pupils at the hospital, a James Molins, kept a notebook in which he recorded forty-nine case reports and in nearly all fatal cases gave an account of an autopsy examination, which he apparently carried out himself. Most of these reports are sufficiently detailed to allow us to make a diagnosis today. The range of pathological processes found was not so very different from today and, perhaps surprisingly, malignant tumours were the commonest cause of death in this small series.

Occasional comments by Molins suggest that he took a keen interest in his pathological studies and tried to correlate clinical and pathological findings. For example, in a case of a woman with a tumour of the ovary with metastases in the liver and dropsy he remarked 'kidneys sound and good which are, as I may confidently afirm, soe in all Hydropicall persons'. Again, he recorded the case of a porter with a swelling of the thigh which was incised and who developed chest pains and cough 'which I suppose was the metastasis of the matter upon the lung' and indeed at autopsy the lungs were 'full of harde glandulose knobs'.

Almost contemporary with Molins was another student of morbid anatomy, the surgeon John Brown who in 1685 gave the earliest description of cirrhosis of the liver, in an alcoholic soldier dying in the hospital. ${ }^{2}$

During the whole of the eighteenth century, clinicians continued to study morbid anatomy but probably not very intensively, the next important landmark in the history of pathology at St. Thomas's being W. C. Wells's famous paper published in 1810 on the relation between acute rheumatism and heart disease which was based on a clinico-pathological study of patients in the wards and dead house of the hospital. ${ }^{3}$

The work of Wells brings us almost to the threshold of that great era of morbid anatomy linked with the names of Laennec, Rokitansky and Virchow on the Continent, and of which Addison and Bright at Guy's Hospital were the brightest stars in this country. It is unfortunate that at this period of medical history, just as advances in medicine were beginning to gather momentum, the fortunes of the hospital and particularly its associated medical school were at 


\section{History of Pathology at St. Thomas's Hospital, London}

a low ebb. The split with Guy's Hospital Medical School had occurred in I825, and although for a few years the St. Thomas's School appears to have held its own it soon began to decline. In 1842 the nadir of the school's affairs had been reached and J. H. Green, a surgeon to the hospital, gave it as his opinion that the unprosperous state of affairs was due to the unpopularity of the lecturers, the rivalry with the two new schools, University College and King's College, which had the advantage of close liaison with London University, the rivalry between members of the school and hospital staff, the frequent change of lecturers, and the fact that fewer men were taking up medicine.

It was decided that the school must be drastically remodelled and in July I 843 the new era began. Amongst the most important changes was the introduction of Richard Grainger, who already ran a most successful private medical school, to teach physiology and bring his pupils with him. From this time on, amidst their many problems, the committee of medical and surgical officers of the hospital and lecturers to the medical school had to make provision for the study and teaching of pathology, and it is from their minutes, which are extant to the year 1880 , that we can trace the history of our subject to that date. ${ }^{4}$

The first relevant problem which faced the committee was the maintenance of the museum which at that time played a very important part in teaching. Museums were commonly the private property of the various lecturers and were of considerable value; for instance, at the separation of Guy's, St. Thomas's bought the whole museum for $£ 2,000$. The committee considered the qualities necessary for a curator and decided that they needed a man who was a competent, comparative and morbid anatomist who was skilled in dissection and in making injected preparations. He was to be assisted by a subcurator who could make preparations, casts and drawings to illustrate lectures. They also advertised for an artist to make drawings of preparations, and to combine this work with the duties of librarian. A Dr. Adams was put in charge of the museum and was required to attend between 9 a.m. and 5 p.m., and Dr. William Munk (later to become well known as the author of the Roll of the College of Physicians), who did the post-mortems was asked to assist. Later in the year George Rainey was appointed assistant in the museum at a salary of $£$ ioo per annum for one year. His connexion with the hospital lasted sixty years, and although he never reached any great heights in his profession he was one of the most original and industrious research workers and one of the most popular teachers at St. Thomas's during the nineteenth century.

During the following year the question as to whether it was desirable to make greater provision for the study and teaching of pathology was discussed, but the 'Committee having considered the appointment of a lecturer in pathology are of the opinion that it is inexpedient and unnecessary to appoint any lecturer in that subject', the prospectus already naming Dr. Munk as demonstrator in morbid anatomy. However, less than two years later the Committee decided that 'the appointment of a chair of pathology, with increased facilities of research would be conducive to the advancement of medical science and advantageous to the school', but they added a rider which perhaps hints at some of the reasons why the step had not been taken two years previously, 'that in any 


\section{W. D. Foster and F. L. Pinniger}

arrangement to be subsequently carried out, it is essential that the position and character of those already attached to medical and surgical staff of the hospital should not be injuriously affected'.

As a result John Simon was appointed first lecturer in pathology in 1847 on very advantageous terms-a salary of $£ 200$ per annum and with charge of some surgical beds. He was twenty-eight years old on appointment and his main life's work was to be more in the field of public health.

He immediately set to work to organize the pathological work of the hospital with a view to raising the standard and making the material and results of investigation available for research. He had the ear of the all-powerful Treasurer, Mr. Baggallay, to whom he showed the method of recording case-histories and post-mortem reports in a book practised at St. George's Hospital, and persuaded him that such a system would be beneficial in St. Thomas's. The Treasurer wrote to the Committee that he heard 'from all quarters without our walls' of the great importance of this line of work and it was resolved that a plan for a post-mortem record book should be drawn up. It was also suggested that the lecturer in pathology enter up the results of any 'investigations made by means of the microscope or chemical analysis'.

This record book of Simon's did not prosper, at least initially. Two months later the form of the book had not been decided, and the Treasurer, no doubt at Simon's instigation, wrote to the Committee requesting that the matter 'be no longer delayed'. The Committee requested Simon to deal with the matter. Still all was not well. The book was drawn up, but five months later, again no doubt at Simon's instigation, the Treasurer wrote to the Committee complaining in strong terms that in the case-history book 'not one entry of any medical officer appears', and in the post-mortem book 'four post-mortems only are recorded and they are all by Dr. Simon'. Mr. Baggallay went on to say that it was no good leaving it to the librarian to copy case notes from the bed card into the book, and accused the medical and surgical officers of 'a great neglect'.

The Committee was, not unnaturally, incensed by this letter, and one wonders what Simon's relations with his colleagues can have been like. Dr. Barker drew up a long letter of reply, the gist of which was that with regard to the Treasurer's complaints the medical officers could not have been negligent since 'all these duties devolve on others'. Barker informed his colleagues that the Treasurer seemed satisfied with his letter, but they were speedily disabused by another letter from the Treasurer expressing his dissatisfaction in no uncertain terms. The medical officers, however, were not to be brow-beaten and replied that 'we cannot however but think that on reflection you will deem it unreasonable that the time of the medical officers should be occupied in the recording of cases as to interfere seriously with their private engagements', and they suggested the appointment of 'a young physician' specially to draw up these abstracts-the origin of the medical registrar. Meanwhile Simon continued to make his presence felt. He proposed that an entrance examination in mathematics, moral philosophy, natural history, physics, classics and modern languages be inaugurated and also proposed a prize for original work done by students. The anatomists were constrained to apply for another room, one of theirs having 


\section{History of Pathology at St. Thomas's Hospital, London}

been appropriated by the 'professor of pathology'. In June 1849 Simon began his course of lectures on general pathology, lecturing on Mondays and Fridays at 1 I a.m. These lectures he published in $1850,{ }^{5}$ and they gave an excellent notion of the general pathological knowledge of the time. Simon's zeal for his subject and indeed for the welfare and improvement of the school cannot be doubted, but he cannot have been an easy colleague. In April 1850 he presented the Committee with a bill for instruments for the 'Pathological room', which after discussion it was agreed should be paid, but it was resolved that in future no lecturer should order goods on his own authority.

The management of the museum under Dr. Adams had become unsatisfactory. In June $1848 \mathrm{Mr}$. Barron, who held the office of 'conductor of postmortems', resigned and the Committee resolved, perhaps without consulting him, that Adams should be temporarily responsible. In October 1849 he was still doing the post-mortems, but evidently reluctantly, and not to Simon's satisfaction. Adams was told that he must be more punctual. The museum meanwhile had fallen into a state of disorder, doubtless partly due to Adams's idleness, but the fault cannot have been entirely his. The Committee expected a good deal of their curator, and the work of cataloguing the specimens must have been very laborious even though the task of cataloguing the various categories of specimens had been distributed among some of the members of the staff, an arrangement well calculated to cause confusion. The Committee must have felt that Adams was overworked for he was relieved of the responsibility of doing the medical post-mortems, whilst continuing the surgical. Volunteers to do the medical post-mortems were called for, but there is no record of anyone coming forward. Conducting autopsies in the middle of the nineteenth century was an unpleasant business and by no means free from the danger of severe and even fatal infections. ${ }^{6}$ Indeed in 1874 the Committee resolved that an additional payment of $£ 5^{\circ}$ per annum be paid 'considering the great risk and labour incurred' in doing post-mortems.

Adams was able to effect little improvement in the organization of the museum, and its catalogue remained uncompleted for several years. Adams continued to complain of overwork and, although he was afforded some assistance, he sent in a letter of resignation. He requested, however, that he might have some honorary position to 'permit him to say that he has some connexion with St. Thomas's hospital', but the Committee regretted 'that they were unable to suggest an appointment of the description alluded to'. Adams then wrote to say that he had not intended his letter as one of resignation and requested some honorary connexion with the dead house. The Committee resolved that he be allowed to do the surgical post-mortems if he would devote time to them. This arrangement proved unsatisfactory, and his connexion with the hospital seems to have been dissolved about 1853 .

In fact, the Committee had been fortunate enough to find just the man it was looking for to succeed Adams. In 1850, after a brilliant student career J. S. Bristowe, whose capacity for hard work was boundless, qualified at the hospital. He was appointed to assist Adams in February $185^{\circ}$ and to have $£ 5^{\circ}$ per annum of the $£$ I 50 paid to Adams. He also demonstrated in anatomy, did the 


\section{W. D. Foster and F. L. Pinniger}

medical post-mortems (and later the surgical ones when Adams defaulted) and lectured on botany. Not content with these duties, he did his best to succeed to Grainger's lectures on physiology when the latter wished to give them up. On receipt of Adams's letter of resignation the Committee appointed Bristowe to succeed him, his salary being increased by $£ 75$ per annum. In July 1854 the museum catalogue was still uncompleted and it was suggested that the whole project be put into Bristowe's hands, his salary to be increased by a further $£ 50$.

With Simon as lecturer, Bristowe as curator, and Rainey, who, although really an anatomist, did much work of a pathological nature-particularly microscopical work - the department of pathology was in a flourishing state. All three men were prodigious workers, active in research and good teachers. The nucleus of the department consisted of the lecturer and curator, and usually there was some assistance in the way of assistant curators who helped in the museum or did some of the post-mortems. The basic pattern of pathology at St. Thomas's was set in the 1850 , not to be much altered except in detail until the last decade of the century, but some of these details are of interest and may be considered at this point.

For many years post-mortem examinations constituted the most important part of pathology, being of particular importance in an era when diagnosis aimed at expressing disease in terms of localized anatomical lesions and was arrived at by a careful physical examination of the patient. The work cannot have been pleasant, the actual danger has been alluded to, and the problem of getting them done, particularly at a time of the day which suited all concerned, caused recurring difficulties. We have mentioned the early difficulties in getting the results of autopsies recorded, but by February $185 \mathrm{I}$ the post-mortem book was up to date with records of 460 autopsies which gives an approximate rate of 150 autopsies per annum since the record book was started. The procedure for recording was that the prosector made some rough notes which were copied fair by the librarian into the post-mortem book. This was clearly laborious and resulted in the arrears already mentioned. It was therefore resolved that the actual notes made by the prosector should be bound and the prosectors were requested to write legibly.

It was the duty of the clinical clerk of the case or the houseman to attend all autopsies and furnish clinical details, a duty of which it was necessary to remind them. That there was still a shortage of subjects for the anatomical dissecting room is revealed in a resolution which subordinated the interests of the pathologists to the anatomists, it being resolved that 'the body of no patient dying in the wards of the hospital shall be submitted to a port-mortem examination in the dead house, if there be any reason to believe that such a body can be procured for the use of the dissecting room'.

The clinical staff felt that autopsies should be performed on all patients dying in the hospital, but the Treasurer would not agree to this if the patient or his friends had any objection. He stressed that they must avoid hurting anyone's feelings, an unexpected humanity when one considers the times and the class of persons constituting the hospital patients.

The microscope as a tool in practical medicine was introduced about 1840 , 


\section{History of Pathology at St. Thomas's Hospital, London}

and the teaching staff were quick to appreciate its importance. As early as 1843 Grainger asked for money to buy a microscope for the museum, and a grant of $£ 50$ was voted for this purpose.

George Rainey was the person to take up microscopy with enthusiasm. In 1847, having been appointed assistant in the museum, he joined with Grainger to give microscopical demonstrations to the students. We also know that the microscope began to be used in diagnostic pathology in the same year, for it was laid down that the lecturer in pathology should record in the post-mortem book any 'investigations made by means of the microscope'. By the end of 1849 there was a special room known as the 'microscope room' which was under the general supervision of Grainger and Simon, but in the immediate charge of Rainey, who gave a microscopical demonstration once a week, and spent a considerable part of his time adding to the school's collection of microscopical preparations. Such accommodation as Rainey had was evidently inadequate by I 85I, for he requested and was allowed the use of a small room off the dissecting room in which to give practical instruction in the use of the microscope. That the value of microscopy was keenly appreciated is evident from the request of two of the students, a Mr. Bury and a Mr. Chipperfield, that the microscope room should be made available to them. Their request was allowed, but evidently not implemented because four months later the Committee received a letter signed by nineteen students complaining of the difficulty they had in getting access to the 'hospital microscope'. It was therefore resolved that a second 'inexpensive microscope' be bought for the use of the students and put in charge of the librarian.

From these small beginnings the number of microscopes in the hospital gradually increased. In 1860 the curator of the museum requested that a microscope be supplied exclusively for the use of the museum and in $1876 \mathrm{~W}$. S. Greenfield, who had recently succeeded Bristowe as lecturer, also requested a microscope of his own, and we know that by the 1890 all the wards were supplied. In 1864 it was laid down as part of the duties of the curator of the museum that he 'shall anatomically and microscopically examine such morbid products as are brought to him from the operating theatre, or otherwise referred to him from the practice of the hospital and shall enter in a book (to be kept by him specially for this purpose) his reports on every such product'.

In 1874 the Committee recommended that the school start a special course in practical microscopy specially related to human physiology and pathology which should be open to practitioners as well as students for a fee.

Chemical pathology is second in seniority of the four main branches of pathology and in a crude form dates back to the seventeenth century. At St. Thomas's, James Molins, whose post-mortem records have been discussed, performed crude chemical tests on the clot found in the heart of one of his cases. The modern development of chemical pathology dates from the early years of the nineteenth century and stems from analytical work on the blood, done particularly in France by G. Andral, and also from the discovery of the significance of albuminuria. In this latter field the work of the St. Thomas's physician, W. C. Wells, was of the greatest importance as he, with Blackall of Exeter, was 


\section{W. D. Foster and 7. L. Pinniger}

one of the first to draw attention to the association of albuminuria with dropsy. ${ }^{7}$ There is no record of further work in chemical pathology for many years after that of Wells, but there is an indication that some attempts were made at chemical analysis of post-mortem material at least. A knowledge of chemistry had long been considered an essential part of a doctor's profession and had been taught since the eighteenth century, but this chemistry was treated more as a pure science or oriented towards materia medica and toxicology, so that, despite an active department of chemistry, there was no study or teaching of chemical pathology in the middle of the nineteenth century.

That the great activity in the field of organic chemistry at this time was making its impact is exemplified by Simon's opinion 'that all the most important improvements which can be made in the treatment of disease will be due to previous discoveries in the science of pathological chemistry'. He considered that twenty years hence no hospital would be considered up to standard without adequate facilities.

That the medical officers were aware of the possible value of chemistry to the pathologist is indicated by the proposal to spend the comparatively large sum of $£_{1}$ o on having the calculi in the museum analysed. In 186 I Dr. Bernays, the lecturer in chemistry, suggested to the Committee that the Treasurer be asked for money to set up a department of chemical analysis 'for cases of poison suspected as well as real, in all cases of diseases of the kidneys, with many others, not only that the officers may arrive at correct conclusions but that the chemicals used might be tested'. $£ 40$ was allocated for this work, but it was generally agreed that the chemical lecturer could not be expected to devote his time to this new project. Simon therefore in 1865 , with the agreement of Bernays, sounded out the Treasurer about the possibility of having a lecturer in chemical pathology with a proper department. Moreover, Simon had just the man in mind to fill the position. Through his connexion with the Privy Council he had met J. L. W. Thudichum, an enthusiast for chemical pathology who had received his training in the laboratory of the great Liebig. Thudichum had been engaged by the Privy Council to carry out some chemical investigations and he was pleased to have a connexion with some large hospital and in return to give a course of twelve lectures per annum gratuitously. The Treasurer was in agreement with these proposals provided the expense of fitting up a laboratory was not too great. It was therefore resolved that Thudichum be 'appointed lecturer on pathological chemistry during the pleasure of the Governors'.

The minutes of the committee of lecturers reveal a number of other interesting facts covering the development of pathology at St. Thomas's. From the earliest days of the school it had been the practice to give prizes to students as a result of examinations in various subjects. They were considered not only as a means of stimulating effort on the part of the student but also as an attraction for students to come to the hospital and the annual prize-giving was something of an event. In 1845 the Prince-Consort distributed the prizes and the school always tried to get some notable for the occasion. Pathology was not considered to be a subject for prize examination until $185^{\circ}$ when the first such prize was awarded to J. W. Keyworth. It was not, however, until ${ }_{185} 6$ that pathology became a 


\section{History of Pathology at St. Thomas's Hospital, London}

subject for the third-year examinations. Even so, pathology did not achieve an equal status with the other subjects in which the students were examined. Nine years later another resolution was passed making pathology and morbid anatomy a distinct subject for examination purposes, to be conducted by the lecturer and demonstrator. A total of 225 marks out of I, 125 were awarded to pathology, but it is noteworthy that the other subjects carried a possible total of 300 marks.

The procedure for appointing junior members of the school staff was raised in an acute fashion in 1867 over the appointment of a demonstrator in morbid anatomy. In those days the Treasurer of the hospital was an all-powerful figure. The school was quite dependent financially on the hospital except for the students' fees which the lecturers divided amongst themselves and the lecturers had to apply to the Treasurer for the smallest sums for school expenses. In November 1866 the Committee, perhaps hearing it rumoured that the Treasurer proposed to nominate a candidate for the vacant post of demonstrator in morbid anatomy, sent him a gentle note pointing out the importance of the subject and the scientific attainments necessary for such a post. Mr. Baggallay, however, failed to take the hint and appointed a Dr. Lees to the vacant post. This called forth a most vigorous letter from the Committe protesting that the appointment was made without the advice of the school and contrary to precedent. Moreover, Dr. Lees was not a suitable person,

his career as a student had not been of conspicuous merit; that subsequently he had given no proof of special aptitude for pathology, nor even special zeal for it, and, that not eighteen months before the late exercise of the Governors' patronage the Treasurer had seen fit to draw the attention of the medical school to Dr. Lees' failure to pass his first M.B. examination.

The lecturers resolved that Lees was quite unacceptable and would not allow him to assist Simon with the pathology examinations.

At a meeting a week later the views of the school committee were expressed in a very long minute, and it was finally resolved that they regretted the Governors' appointment, protested against the title of demonstrator being given to anyone not approved by the school and stated that in their view the office of demonstrator had not been filled by the recent appointment. The gist of the Treasurer's reply was that he had sought the advice of the school, but it seems this had only been in informal conversation with Bristowe who protested 'but little did I think the Treasurer was on the eve of appointing Dr. Lees, on the strength of anything that I had said'. The Treasurer pointed out that the post was wholly paid by the hospital and that he therefore felt that the Governors had the right to make the appointment. He concluded by saying that it was not until three months after the occurrence of the vacancy that he heard that there would be any objection to Dr. Lees and that it would be hard on him to make any change. He could only hope that Lees might 'remove the unfavourable impression which at present exists in the minds of some of our officers'. The Committee were by no means satisfied and expressed themselves 'unable to acquiesce to the Treasurer's interpretations of the proceedings'. However, the Treasurer merely replied that he did 'not think it desirable to prolong the 


\section{W. D. Foster and F. L. Pinniger}

correspondence', and although the Committee tried to make difficulty about including the name of Dr. Lees in the prospectus they finally had to agree.

This controversy over the appointment of the demonstrator took place in the middle of the hospital's short sojourn at the now extinct Surrey Gardens in Newington at a time when the medical school had wilted considerably and the annual average entry had fallen to fifteen. The hospital moved from its Southwark site in 1862 as a result of the expansion of the railway system at London Bridge. The Surrey Gardens consisted of a recreation ground, partly a menagerie and partly a music hall. The elephant house became the dissecting room, the giraffe house a cholera ward, and the great hall was converted to wards for two hundred patients. Florence Nightingale, who had considerable influence over the design of the new hospital in Lambeth, started her training school for nurses in the Gardens. The move to the new hospital, the cost of which amounted to half a million pounds, took place in 1871 . A year earlier John Simon had resigned his post as lecturer in pathology and was succeeded by Bristowe.

Simon's estimate that the future of pathology lay in chemical pathology did not prove immediately correct. The next major development of which hospital pathologists had to take cognizance was the science of bacteriology. Interesting developments began to take place in this field as early as the 1850s, but its importance to the practising doctor was brought home sharply by the discovery in I882 of the tubercle bacillus and Ehrlich's differential staining technique which enabled the organisms to be readily detected in sputum, and other discharges.

It was, none the less, some years before the compelling necessity of a bacteriological laboratory in even large hospitals was felt, but St. Thomas's Hospital appears to have been one of the earliest to appreciate the need and provide for it. The moving spirits in this direction were G. A. Ballance, T. Acland and W. H. Stone. C. A. Ballance, who was later to achieve fame as a pioneer neuro-surgeon, was a graduate of St. Thomas's. He was appointed aural surgeon to the hospital in 1885 and later assistant surgeon and surgeon. T. D. Acland was the son of Sir Henry Acland, Regius Professor of Physic at Oxford. He graduated in 1880 from St. Thomas's and as a Radcliffe fellow visited Leipzig and Vienna-presumably acquiring his bacteriological knowledge there. Although his knowledge of the subject could not have been extensive it must have been unusual for an Englishman, and in $188_{3}$ he was sent to Egypt to fight a cholera epidemic and rapidly became principal medical officer to the Egyptian Army. It was not until I887 that he was elected assistant physician to St. Thomas's Hospital.

W. H. Stone, who presented all the necessary bacteriological apparatus to the hospital, was a more senior man, having been a physician to the hospital since 1870 . His main interest in life was electrotherapy and he lived 'mostly to himself, with his kindly old housekeeper, his owls and his multitudinous apparatus'.

In December 1885 Acland and Ballance demonstrated the bacteriological resources of St. Thomas's Hospital at a meeting of its Medical and Physical 


\section{History of Pathology at St. Thomas's Hospital, London}

Society. The sterilizers and incubators were on show as well as various sorts of culture and media and about fifty different sorts of microbe. They used a total of seventy microscopes in their demonstration, but only twelve of them had oil-immersion lenses. W. Watson Cheyne, one of the most competent of the early British bacteriologists, gave a short address in which he congratulated St. Thomas's on being the first hospital in this field. ${ }^{8}$

The following May, Ballance repeated the demonstration at a meeting of the West London Medico-Chirurgical Society, and in replying to a vote of thanks said that 'it was probably within a measurable distance of time when each medical school would possess a bacteriological laboratory' ${ }^{9}$ From the medical school prospectuses we find that the earliest teaching of bacteriology to the medical students was by S. G. Shattock in I 892 . The department of bacteriology must have been in a flourishing state at the time because in the following year it was visited by the great Virchow. ${ }^{10}$

It was the addition of clinical bacteriology to the old medical microscopy and simple clinical chemistry that made the subject we now know as clinical pathology and as the last decade of the nineteenth century wore on it became apparent to the hospital staff that the arrangements for proper laboratory investigations on patients were inadequate and that they needed a central laboratory in which operation specimens, blood, urine and the various bacteriological specimens could be examined. Here again St. Thomas's Hospital was well in advance of current thought. At this time clinical laboratories had recently been established at Glasgow Western Infirmary, the Brompton Hospital and the various hospitals of the Metropolitan Asylum Board, but, in general, none of the teaching hospitals in this country possessed such laboratories. The beginnings of a clinical laboratory came into existence at St. Bartholomew's Hospital about 1893 because A. A. Kanthack, who was lecturer in pathology to the medical college, was interested in clinical pathology and material from the patients which had been examined in the wards came increasingly to his department.

In 1896 the medical and surgical officers of St. Thomas's Hospital addressed an appeal for the centralized clinical laboratory to the House Committee in which they stated that 'it can hardly be doubted that in the immediate future a clinical laboratory of which an outline is given below, will be considered an essential part of all large general hospitals'.11

The scheme envisaged called for a laboratory under a director with requisite skills, particularly in bacteriology, who was to be assisted by some senior students.

The estimated initial outlay came to a total of $£ \mathrm{I} 55$, but it was suggested that an economy might be effected if some of the microscopes from the wards were transferred to the laboratory. The annual running costs of the laboratory were forecast as $£ 225$, being made up of:

$\begin{array}{lr}\text { Salary of superintendent } & £ \text { 100 } \\ \text { Wages of a boy } & £ 25 \\ \text { Materials } & £ 60 \\ \text { Replenishing and repairs } & £ 40\end{array}$




\section{W. D. Foster and F. L. Pinniger}

The Grand Committee resolved 'that a pathological laboratory as described in the foregoing report be established'.

The clinical laboratory opened in November 1897 under the directorship of Louis Jenner, a young man of thirty-one, some three years qualified, who had previously held the posts of house physician and demonstrator in morbid histology. The laboratory was newly built out on to some wide leads on the first floor in its present position opposite Albert ward. It consisted of a large room $46 \times 17 \mathrm{ft}$., divided into two by a partition. It was well equipped, and each worker had his bench, drawer and sink, with gas and electricity laid on. One of the rooms was reserved for bacteriology and in the other room media were prepared, the blood and urine examinations made and the histological sections cut. These sections were reported on once a week by S. G. Shattock, but otherwise the entire work was done by Jenner with the assistance of four senior students. ${ }^{12}$

During the first thirteen months of the laboratory's existence 1,664 specimens were reported on. Of these, there were:

$\begin{array}{lr}\text { Histological reports } & 535 \\ \text { Throat swabs } & 266 \\ \text { Widal reactions } & 175 \\ \text { Urine examinations } & 110 \\ \text { Sputum for tubercle bacilli } & 40 \\ \text { Red cell counts } & 52 \\ \text { Haemoglobin estimations } & 36 \\ \text { Total white cell counts } & 32 \\ \text { Differential white cell counts } & 4 \\ \text { Examination of blood films } & 47\end{array}$

The function of the laboratory was supposed to be entirely that of a routine, not a research, laboratory but from the beginning some research into the problems arising out of the routine was undertaken. Mention may be made of work on the technical aspects of the newly discovered agglutination reactions, on the value of Ehrlich's 'diazo reaction' in typhoid fever, and it was during his time as director of the laboratory that Jenner developed his combination of methylene blue and eosin which forms the basis of the various routine blood film stains used today. ${ }^{13}$

In October 1900 Jenner resigned his position as he wished to spend more time on bacteriological research. His career after leaving St. Thomas's was, however, short as he contracted typhoid fever whilst working on the toxins of the typhoid bacillus at the Lister Institute and died in 1904. He was succeeded by C. G. Seligman, who qualified from St. Thomas's in 1896 . Seligman resigned in 1903 to go on an expedition to New Guinea, which turned him away from pathology to anthropology as a career and he eventually became President of the Royal Anthropological Institute of Great Britain and Ireland in 1923.

Meanwhile Samuel George Shattock, already mentioned for his teaching of bacteriology and help with the routine surgical histology of the hospital, had been appointed curator of the museum in 1884 . Shattock was also appointed pathological curator to the Hunterian Museum of the Royal College of Surgeons 


\section{History of Pathology at St. Thomas's Hospital, London}

in 1897 and he devoted most of his working life to these two institutions. He became St. Thomas's first professor of pathology in 1913 and was elected Fellow of University College, London, in 1910, and Fellow of the Royal Society in 1920. Shattock's influence on the development of pathology as a scientific discipline in London at the turn of the century was considerable, as was pointed out by Professor A. E. Boycott, one of his erstwhile pupils. ${ }^{14}$

When Shattock reached years of independent activity it was just beginning to be recognized that pathology was a science which could stand on its own feet, and which could no longer be dealt with satisfactorily as a parergon by men whose chief interest was clinical practice. His predecessors had been of that sort and the succession of one who gave his whole time to the study of pathology was a landmark in London, in parallel with the change which began with the appointment of Hamilton to the chair of pathology in Aberdeen in 1882 and which has since become universal. First and last he was a sincere and industrious student who made it his chief business in life to have a scholar's knowledge of his subject. His concept of the extent of pathology was comprehensive. Morbid anatomy was historically and actually the origin but a pathology which did not equally include botany, zoology, clinical medicine, chemistry and physics he likened to some horrid amorphous monster not viable and out of all relation to the laws of decent development. His theory was reflected in his practice: he came to be the acknowledged authority on questions of morbid anatomy and histology, but he wrote on tumours and the healing of wounds in plants, on the experimental search for cancer parasites, on the influence of sewer air, on the virulence of diphtheria bacilli, on the relation of secondary sex characters to the gonad and sex inversion, and he also nearly discovered blood groups.

Shattock became a member of the Pathological Society of London in 1880 , and it was at the meetings of this Society that he exerted his chief influence on the development of pathology in London. By the time the Society was dissolved in its sixtieth year in 1907 to become the Pathological section of the newly formed Royal Society of Medicine he had published some 140 greater or lesser papers there. Shattock continued to attend and contribute to the formal meetings of the new Society until the year before his death, his last communication in 1923 being entitled 'The disruptive phenomena of gunshot injuries: their physics'.

This great scientist and erudite scholar was not the man whom many people at St. Thomas's saw. Shattock was an extremely shy and withdrawn character so that his many and great accomplishments were virtually unknown to those around him. To his colleagues he was a recluse, appearing in the hospital at noon on his way to the Royal College of Surgeons, dressed in the clothes of bygone days, wearing an unbrushed top hat, green fronted frock coat and trousers too long in the leg, and carrying a very untidy umbrella, with a large black bag in his hand, in which he transported his specimens. Otherwise he would only be found in the curator's room or the small bacteriological laboratory which are now partly absorbed into the Anatomy Department and partly the Museum preparation room. Here the venturesome would find him like Sherlock Holmes, with side whiskers and in his untidy frock coat, his various specimens laid out on the dusty benches under bell-jars of different sizes with notices 'do not touch' to frighten off the inquisitive. Shattock was in fact better known to the medical students than to the staff, because although he was too shy to look directly at his audience he was an apt and incisive teacher, being 


\section{W. D. Foster and F. L. Pinniger}

a master of sarcasm and having a keen sense of humour. He would suddenly produce small objects of pathological interest from his waistcoat pocket for the edification of his audience and would beat his specimen jars with such energy that his fascinated audience would feel that they must at any moment burst. 'This, gentlemen, is a gumma of the testis removed by that practical surgeon, Mr. X. He has wasted much valuable time on this subject but more valuable paper.' He would continually scratch the left side of his face with his finger, telling his audience that this was to disprove that injury is a cause of cancer.

Though so elusive that he would cross the road rather than talk to people, no sincere worker who breached his reserve ever applied to him for help and assistance in vain. No one acknowledged this debt more than Leonard S. Dudgeon, who had succeeded Seligman as superintendent of the clinical laboratory in 1903 at the age of twenty-seven, having already been pathologist at the West London Hospital at Hammersmith. Dudgeon, who had qualified from St. Thomas's, remained in charge of the laboratory until his unexpected death after a cholecystectomy in $1938 .{ }^{15} \mathrm{He}$ thus worked with Shattock for twenty-one years and always had a profound veneration and warm affection for the man from whom he acquired a close and precise knowledge of morbid anatomy and histology. All through his career Dudgeon set for himself an exceptionally high scientific standard, and it is notable that he quoted Shattock as one who served pathology well, in preventing the acceptance as fact of work which was nonproven, but in sharing this common standard the two men shared practically their only common feature. Dudgeon indeed was Churchillian in many of his characteristics. He had tremendous drive and a great gift for organization, made others work very hard, did not suffer gladly those he regarded as fools, and did not brook much opposition. These qualities were instrumental in his serving with great distinction as Colonel Consultant Bacteriologist in Salonika, and it was also not surprising that he was elected Dean of St. Thomas's Medical School in 1928. It was inevitable too that Dudgeon should have been disliked by many people: they were usually those who were not in a position to stand up to him, such as his technicians.

Dudgeon made his mark at St. Thomas's while leaving little impact on the pathological world outside because his interests were so largely clinical. He was indeed one of the pioneer clinical pathologists and this orientation of pathology at St. Thomas's was different from that at many other London teaching hospitals and has remained a strong force at the hospital to this day. Dudgeon was often called into the wards to investigate an obscure pyrexia or help with a difficult diagnosis and clinicians such as Sharkey, Clutton, Makins and Wallace were frequently in the laboratory to discuss their problems. Dudgeon also found time to run a considerable private practice which in part was more clinical than pathological. Through his boundless energy, the keeping of many late nights in the laboratory, and his habit of dispensing with lunch, Dudgeon carried out with his clinical colleagues and junior laboratory staff many research investigations. Among his earlier assistants were P. N. (later Sir Philip) Panton, who left to become the first director of the clinical laboratory at the London Hospital, and W. W. G. Topley, who had a similar appointment 


\section{History of Pathology at St. Thomas's Hospital, London}

at Charing Cross Hospital before moving on to become professor of bacteriology at Manchester. In his earlier days his researches were largely bacteriological, such as his demonstration in 1910 of the antiopsonic effect of bacterial extracts. However, Dudgeon's major contribution in research was the development of the technique of exfoliative cytology in 1926 for the rapid diagnosis of tumours of the breast and for the identification of malignant cells in the sputum and pleural and ascitic fluids. Although he launched this technique in the clinical field before Papanicolaou, his insular attitude towards pathological activities in other centres resulted in a delay in the spread of its application elsewhere until Papanicolaou's studies with Traut were published in 1943. Dudgeon's aggressive qualities were expressed in his teaching and he tended to intimidate his students on the occasions of his 'wet meat' or 'rag' classes. However, most of his class could stand up to his methods, which he liked to see them do, and his largely clinical expositions were in general very helpful and popular.

Neither Shattock nor Dudgeon played any material part in the hospital autopsies which continued for many years to be the responsibility primarily of the assistant physicians to the hospital. Indeed, one of the most assiduous of them, G. R. Box, wrote a manual on post-mortem technique in which he advocated the wearing of rubber gloves during dissections. ${ }^{16}$ At the end of the first decade of this century the school prospectus wrote of a new event with some pride: 'The post-mortem room and mortuary are provided with cold storage and ventilated by the electric fan'-a significant commentary on the previous unsavoury conditions. ${ }^{17}$ The pathologists became wholly responsible for post-mortem work in 1926, the last physician to resign his post being Dr. (later Sir Henry) Letheby Tidy.

A substantial new building for pathology was completed in I902, the west wing of the Medical School. The first floor was used for the teaching of students, and the ground floor was designed to be

the Hospital Laboratory of Pathology which has recently been established by the Governors and is reserved for extended investigations of the pathological material provided by the postmortem work of the hospital. Besides the main laboratory subsidiary work rooms are provided and the whole is completely equipped for all purposes of microscopical, chemical, and bacteriological research. It is under the charge of the assistant pathologist who acts as director and is open to senior students who will be encouraged to follow out any special line of research. ${ }^{18}$

This could well have formed the nucleus of an Institute of Pathology under professorial direction making a major contribution to advance in pathological research in this country, but in fact within a few years it was defunct. Shattock was too much of a lonely individualist, and Dudgeon too clinical. The first and only director was C. Powell White, who later achieved distinction as director of the Helen Swindells Cancer Research Laboratory in Manchester, and became the first President of the Association of Clinical Pathologists, but who appeared to be a complete misfit at St. Thomas's. ${ }^{19}$ After his resignation, and until Professor Barnard succeeded Dudgeon, the west wing served only as classrooms for medical students.

The facilities for work in the clinical laboratory, now renamed the Louis 


\section{W. D. Foster and F. L. Pinniger}

Jenner laboratory, during the first decade of Dudgeon's direction, seem to have been quite adequate for the demands made upon them. The number of specimens examined annually had fallen from the 1,664 of its first year of existence to 1,205 in 1903 , but in 1907 over 2,000 specimens were being dealt with, the increase of work being largely made up of out-patient bacteriology and the newly introduced vaccine production. By 1912 the laboratory was examining over 2,500 specimens a year, but it was felt that still more use should be made of the clinical material in the wards. ${ }^{20}$ The medical and surgical officers' committee under the guidance of Dr. Turney took the view

that investigations of the origin and nature of a disease is as truly a duty of a hospital as the diagnosis and treatment of individual cases, that this larger investigation cannot be separated from the smaller purpose of immediate diagnosis for which the clinical laboratory was originally founded, and that such an investigation necessitates an extension of the scope of the work hitherto done in the clinical laboratory.

Thus was the path laid open for the rebirth of chemical pathology. It was recommended that the clinical laboratory should be enlarged northwards to form two more rooms, one a work room and the other to house an expert chemical pathologist, to be appointed at a salary of $£ 400$ per annum. The whole was still to be under the control of Dudgeon, the Director of Hospital Laboratories. In addition one or two qualified men were to be appointed to the laboratory at salaries of not more than $£ 200$ per annum: the first person appointed to such a post was A. D. Gardner, who later became professor of bacteriology and afterwards regius professor of medicine at Oxford. The Governors agreed to the proposal of the medical officers, the work was immediately put in hand, and Dr. Hugh Maclean of the Lister Institute was appointed the chemical pathologist. By January 1913 he was at full work in the chemical laboratory. Maclean's ability was immediately appreciated, and in 1914 he and Dudgeon, although not full members of the staff, were allotted fourteen beds for research purposes, the former working on 'certain metabolic diseases and glycouria and diabetes'. In the same year Maclean's salary was raised to $£ 600$ per annum to prevent his accepting a post in Toronto which had been offered to him. ${ }^{21}$

The advent of the First World War brought about a great reduction of pathological activities at St. Thomas's Hospital as elsewhere. Dudgeon went to Salonika as already recounted, and Maclean, commissioned in the R.A.M.C. in 1917 , set up a laboratory at Etaples under the Trench Nephritis Committee, where he examined 60,000 men for signs of renal disease before they went to the trenches. He had the help of O. L. V. S. de Wesselow, an old St. Thomas's student, who had been carrying out biochemical research at the Lister Institute before enlisting as a combatant soldier, and who returned to research under the insistence of Sir Wilmot Herringham and Sir John Rose Bradford.

Dudgeon and Maclean returned to St. Thomas's Hospital in 1919, and the laboratories quickly became active again, the Grand Committee of the Hospital noting in 1920 with respect to increased laboratory expenditure: 'The Louis Jenner Laboratory of Pathology, Bacteriology and Chemical Pathology has 


\section{History of Pathology at St. Thomas's Hospital, London}

developed.' Dudgeon was given the title of Professor of Pathology on his return, the university probably having retired Shattock as he was then sixty-seven years of age, though he continued to work in his rooms in the Medical School until just before his death. Towards the end Shattock showed signs of arteriosclerosis and he died of pneumonia in 1924 .

In February 1920 de Wesselow renewed his association with Maclean by taking up an appointment as his assistant. The following month Maclean was recommended to be director of the newly formed medical unit, and in November of the same year was elected physician to the hospital as well as professor of chemical pathology in the University of London. With these new appointments he relinquished the post of chemical pathologist to the hospital in favour of de Wesselow. Meanwhile Sir Cuthbert Wallace had been appointed the first part-time director of the surgical unit, no surgeon being prepared to drop his income obtained through private practice to become full-time professor. $\mathrm{He}$ straightway invited S. G. Dyke to initiate the unit pathology department. In due course this laboratory came to work in closer collaboration with the medical unit and to a considerable degree was independent of the Louis Jenner laboratory. The expanding activities of the medical unit and chemical pathology were badly in need of more laboratory space, the end room at the north end of the Louis Jenner laboratory being by now quite inadequate. The Governors of the hospital were therefore glad to accept the offer made in 1922 by the trustees of Sir William Dunn, a wealthy South African banker, through the Medical Research Committee, of $£ 5,000$ 'to provide a laboratory to be conducted under the professor in charge of the medical unit for fuller investigations of disease and methods of treatment'. ${ }^{22}$ The new Dunn laboratory situated immediately above the Louis Jenner laboratory was officially opened by the Marquess of Cambridge on 14 June 1923 , when a further gift of $£ 5,000$ by the trustees was announced to purchase additional equipment. The partnership of Maclean, by now Professor of Medicine, and de Wesselow prospered. Maclean had published a monograph on lecithin and allied substances, and a Medical Research Council Report on his war work in 1919. With de Wesselow he published in 1920 an account of a useful, sensitive test of renal function - the urea concentration test. He also devised a new simple and reliable method for the estimation of bloodsugar levels and wrote of his experience with sugar tolerance studies in 1921 . He popularized the alkali treatment of peptic ulceration, and in I923 some of the first insulin used in this country was made in Maclean's laboratories. ${ }^{23}$ In 1924 de Wesselow published what was virtually the first modern book on chemical pathology to be published in this country. ${ }^{24}$ The same year Maclean visited the United States of America as a result of which the hospital obtained a grant of $\mathcal{E}_{15}, 000$ from the Rockefeller Foundation for the purpose of building new unit laboratories on the condition that a similar sum was provided by the Governors of the hospital, which sum was forthcoming from the medical and surgical staff and the teachers of the school. The medical and surgical units settled into the new laboratories opposite the casualty department and continued there until the outbreak of the Second World War. On the resignation of Maclean in I93I, following the onset of his depressive illness, de Wesselow was appointed the next 


\section{W. D. Foster and F. L. Pinniger}

year to succeed him as director of the medical unit, physician to the hospital, and professor of medicine in the University of London; he continued to be lecturer in chemical pathology. Dyke resigned his post as pathologist to the units in 1924 and was succeeded by R. J. V. Pulvertaft. Following the latter's resignation in I931, a minute of some interest appears in the school council meeting of December 1931:

Sir Percy Sargent said that hitherto the Units Laboratory had been dissociated to a great extent from the Professor of Pathology. It would be a great advantage henceforth if the Units Laboratory came under the direct supervision of Professor Dudgeon who would supervise the pathology and teaching of the Units.

This recommendation meant that Dudgeon was now in effective control of all the pathology at St. Thomas's apart from the V.D. laboratory. The latter had been created in 1921 by Colonel L. W. Harrison, the first director of the newly opened V.D. clinic operating in the hospital casualty department. L. N. Orpwood Price and E. J. Wyler, well known for their contributions to the serological diagnosis of syphilis, were among Harrison's first laboratory assistants.

Dudgeon died after a cholecystectomy in 1938 and was succeeded as director of the Louis Jenner laboratory by J. Bamforth. The Chair of Pathology went to W. G. Barnard, who was also put in charge of all pathology departments. Their tenure of office in London was soon to be interrupted by the onset of the Second World War, which led to the evacuation of the pathological laboratories to Kingston and Godalming in Surrey where in addition to their medical school activities they formed part of the Emergency Medical Service.

After the end of the war came the National Health Service and a widening relationship between the University of London and the teaching hospitals. Both have led to meteoric developments of the pathology departments at St Thomas's as elsewhere, well shown by the fact that in contrast to the 2,500 routine investigations recorded above as having been undertaken in 1912 and approximately 10,000 in 1938 , the figure reached 120,000 in 1960.

\section{REFERENCES}

I. PAyne, J. F., Anatomical and practical observations in St. Thomas's Hospital, 1674-1677, by James Molins, St. Thos. Hosp. Rep., 1894, 23, I.

2. Brown, J., A remarkable account of a liver appearing glandulous to the eye, Phil. Trans. roy. Soc., 1685, 3, 248.

3. Wells, W. C., On rheumatism of the heart, Trans. Soc. Improv. med. chir. Knowledge, 1812, 3, 373 .

4. MS. Minutes of the Committee of lecturers of St. Thomas's Hospital.

5. Simon, J., General Pathology as Conducive to the Establishment of Rational Principles for the Diagnosis and Treatment of Disease, London, H. Renshaw, 1850.

6. Foster, W. D., A Short History of Clinical Pathology, Edinburgh, Livingstone, I96I, p. 7 . 


\section{History of Pathology at St. Thomas's Hospital, London}

7. Wells, W. G., On the presence of the red matter and serum of blood in the urine of dropsy which has not originated from scarlet fever, Trans. Soc. Improv. med. chir. Knowledge, 1812, 3, 194 .

8. Bacteriology at St. Thomas's Hospital, Brit. med. F., I886, i, 34 .

9. Bacteriology, Brit. med. F., 1886, i, 1033 .

10. MS. Minutes of the Almoners' Committee of St. Thomas's Hospital, 15 March 1893 .

I I. MS. Minutes of the Grand Committee of St. Thomas's Hospital, 9 December 1896.

12. Jenner, L., The clinical laboratory, St. Thos. Hosp. Rep., 1897, 26, 193.

13. - A new preparation for rapidly fixing and staining blood, Lancet, I 899, i, 370.

14. Вочсотт, A. E., Samuel George Shattock, 1852-1924, Proc. roy. Soc. B., I924, 96, $\mathrm{xxx}$.

15. Oвitu ARy, St. Thos. Hosp. Gaz., 1938, 36, 545.

16. Box, G. R., Post-mortem Manual, London, Churchill, igro.

17. St. Thomas's Hospital Medical School Prospectus (1906-7), London, Griffith, p. 12.

18. St. Thomas's Hospital Medical School Calendar and Prospectus, London, Griffith, 1903-4, p. 20.

19. Dean, H. R., Charles Powell White, 7. Path. Bact., 1931, 34, 581.

20. MS. Minutes of the Medical and Surgical Officers of St. Thomas's Hospital, 30 May 1912.

21. Ibid., 22 October 1914.

22. The Times, 14 June 1923.

23. Griffit hs, W. J., Professor Hugh Maclean, St. Thos. Hosp. Gaz., 1958, 56, 3.

24. De Wesselow, O. L. V. S., The Chemistry of the Blood in Clinical Medicine, London, Benn, 1924. 